\title{
ТЕХНИКО-ТЕХНОЛОГИЧЕСКИЕ
}

ИННОВАЦИИ

DOI: http://dx.doi.org/10.15688/jvolsu10.2015.4.5

УДК 669.017

ББК 24.4

\section{MOLECULAR MODELING \\ OF THE 2-(PYRIDIN-2-YL)-1H-BENZIMIDAZOLE INTRAMOLECULAR DYNAMICS}

\section{Elena Vladimirovna Raksha}

Candidate of Chemical Sciences, Associate Professor, Department of Physical Chemistry, Donetsk National University elenaraksha@donnu.edu.ua Universitetskaya St., 24, 83055 Donetsk, Ukraine

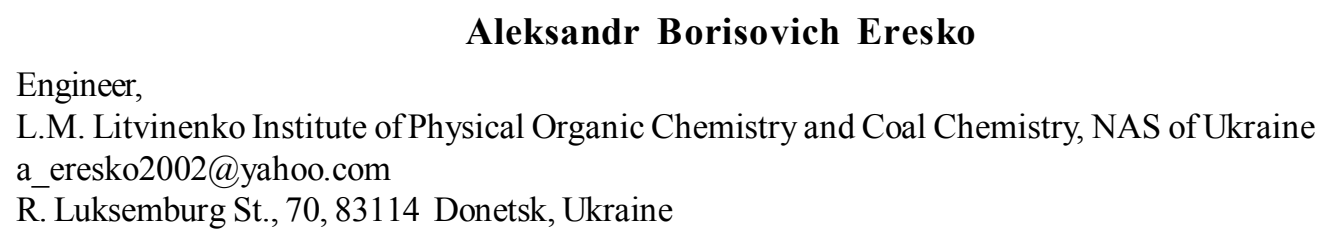

\section{Yuliya Vasilyevna Berestneva}

Postgraduate Student, Department of Physical Chemistry, Donetsk National University berestnevayuv@mail.ru Universitetskaya St., 24, 83055 Donetsk, Ukraine

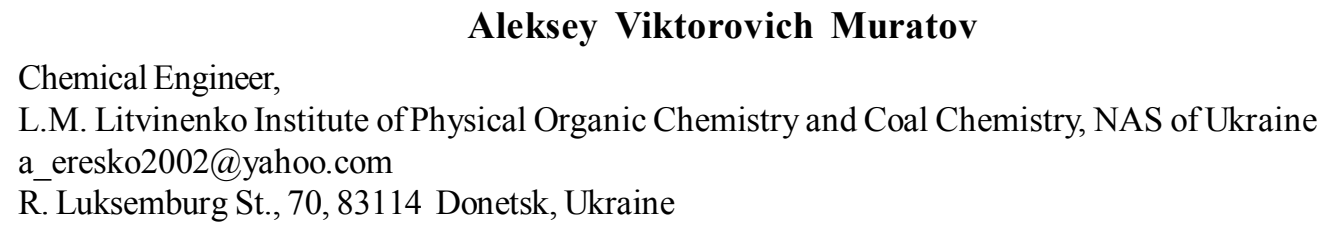

\section{Gennadiy Efremovich Zaikov}

Doctor of Chemical Sciences, Professor, Head of Department of Biological and Chemical Physics of Polymers, Institute of Biochemical Physics named after N.M. Emanuel, RAS

chembio@sky.chph.ras.ru Kosygina St., 4, 119334 Moscow, Russian Federation 


\begin{abstract}
The results of the DFT and MP2 theoretical investigation of 2-(pyridin-2-yl)$1 \mathrm{H}$-benzimidazole intramolecular dynamics are presented. The structural parameters of 2-(pyridin2-yl)-1H-benzimidazole conformers were obtained by these methods; barriers of internal rotation were estimated. GIAO-calculated NMR chemical shifts $\left({ }^{1} \mathrm{H}\right.$ and $\left.{ }^{13} \mathrm{C}\right)$ as obtained at various computational levels are reported for the 2-(pyridin-2-yl)-1H-benzimidazole conformers. The comparative analysis of experimental and computer NMR spectroscopy results revealed that the GIAO method with B3LYP/6-31 G(d,p) level of theory and the PCM approach can be used to estimate the NMR ${ }^{1} \mathrm{H}$ and ${ }^{13} \mathrm{C}$ spectra parameters of the 2-(pyridin-2-yl)-1H-benzimidazole.

Key words: intramolecular dynamics, 2-(pyridin-2-yl)-1H-benzimidazole, chemical shift, magnetic shielding constant, GIAO, molecular modeling.
\end{abstract}

\section{Introduction}

Benzimidazole derivatives are promising leading compounds in the design of substances with antimicrobial, antiviral and anticancer activity [16]. Introduction of pyridine fragment to the benzimidazole structure provides additional coordination center and offers opportunities to create new biomimetic catalytic and sensor systems. 2-(pyridin-2-yl)-1H-benzimidazole (PBI) is a very versatile multidonor ligand displaying three potential donor atoms, one $\mathrm{sp}^{3}$ - and two $\mathrm{sp}^{2}$ hybridized $\mathrm{N}$-donors, and is particularly interesting in view of its own pharmacological properties as an antibacterial [12] and anti-inflammatory agent [15]. PBI is a key structural element in the design of the allosteric activators of glucokinase [6], PBI and other benzimidazole 2-aryl derivatives show high anticancer activity [13]. PBI complexes with Pd (II) are effective catalysts for the Heck reaction [6], in the case of Co (II) complexes are sensors for the amino acids determination in aqueous media. Neutral and cationic mono- and dinuclear $\mathrm{Au}(\mathrm{I}) / \mathrm{Au}(\mathrm{III})$ complexes derived from PBI show antitumor properties [3]. PBI and its derivatives have interesting photochemical and photophysical properties [5]. This provides PBI using as a model compound for the determination of water content and proton transfer processes investigations in membrane fuel cells [5; 7-9].

The efficiency and selectivity of these systems will depend on the conformational properties of the piridynil as well as benzimidazole fragments. The intramolecular dynamics of the PBI was investigated experimentally by NMR ${ }^{1} \mathrm{H}$ and ${ }^{13} \mathrm{C}$ spectroscopy [18]. The aim of this work is a comprehensive study of the PBI intramolecular dynamics as well as its NMR ${ }^{1} \mathrm{H}$ and ${ }^{13} \mathrm{C}$ spectra by DFT and MP2 methods.

\section{Experimental}

PBI was obtained as reported elsewhere [14]. ${ }^{1} \mathrm{H}$ and ${ }^{13} \mathrm{C}$ spectra were recorded in DMSO- $\mathrm{d}_{6}$ on 400/100 MHz NMR spectrometer (Bruker Avance II 400) and chemical shifts values ( $\delta$ ) are given in parts per million relative to tetramethylsilane(TMS). Solvent, DMSO- $\mathrm{d}_{6}$ was Sigma-Aldrich reagent and was used without additional purification.

Molecular geometry and electronic structure parameters, thermodynamic characteristics of the 2(pyridin-2-yl)-1H-benzimidazole conformers were calculated using the Gaussian 09 [4] software package. Geometric parameters, harmonic vibrational frequencies, and the vibrational contribution to the zero-point vibrational energy were determined after full geometry optimization in the framework of B3LYP/ 6-31G and B3LYP/6-311G(d,p) density functional calculations as well as MP2/6-31G ones. The optimized geometric parameters were used for total electronic energy calculations by the B3LYP/6-31G, B3LYP/6311G(d,p), and MP2/6-31G methods. The 6-31G basis set was used in this work because it has a low computational cost. The B3LYP/6-311G(d,p) method was used to elucidate the effect of basis set extension on the results of calculations.

Fig. 1 presents $\mathrm{PBI}$ molecule atom numbering used for geometric and ${ }^{1} \mathrm{H}$ and ${ }^{13} \mathrm{C}$ NMR spectra parameters.

The magnetic shielding tensors $(\chi, p p m)$ for ${ }^{1} \mathrm{H}$ and ${ }^{13} \mathrm{C}$ nuclei of the $\mathrm{PBI}$ conformers were calculated with the MP2/6-31G(d,p) and MP2/6-31G(d,p)/PCM optimized geometries by standard GIAO (GaugeIndependent Atomic Orbital) approach [17]. The calculated magnetic isotropic shielding tensors, $\chi_{i}$, were transformed to chemical shifts relative to TMS, $\delta_{i}$, by $\delta_{i}=\chi_{\text {ref }}-\chi_{i}$, where both, $\chi_{\text {ref }}$ and $\chi_{i}$, were taken from calculations at the same computational level. The solvent effect was considered in the PCM 
<smiles></smiles>

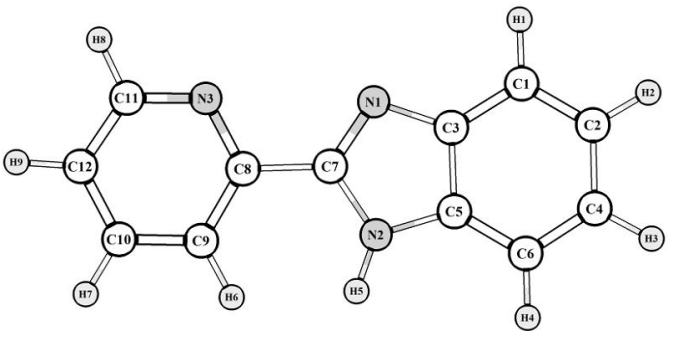

Fig. 1. Atom-labeling scheme of PBI molecule

approximation $[2 ; 11] . \chi$ values for magnetically equivalent nuclei were averaged.

Inspecting the overall agreement between experimental and theoretical spectra RMS errors $(\sigma)$ were used to consider the quality of the ${ }^{1} \mathrm{H}$ and ${ }^{13} \mathrm{C}$ nuclei chemical shifts calculations. Correlation coefficients $(R)$ were calculated to estimate the agreement between spectral patterns and trends.

\section{Results and Discussions}

\section{Conformers and rotational barriers}

The potential energy pathway for internal rotation in PBI molecule was estimated by optimizing the molecular geometries with different dihedral angle between the two aromatic planes. The barriers to internal rotation were calculated within the framework of B3LYP/6-31G, B3LYP/
6-311G(d,p), MP2/6-31G and MP2/6-311G(d,p) methods. The dependence of the potential energy on the dihedral angle (Fig. 2) was determined by scanning the dihedral angle $\mathrm{N}(1)-\mathrm{C}(7)-\mathrm{C}(8)-\mathrm{C}(9)$ (used as internal rotation coordinate $\Theta$ ) from 0 to $360^{\circ}$ with an increment of $15^{\circ}$ and geometry optimization in each step. Rotation was performed sequentially about the $\mathrm{C}(7)-\mathrm{C}(8)$ bond. At each energy minimum, the molecular geometry was fully optimized. The analysis of vibrational frequency was also performed at the same level of theory, and the calculation results revealed that the PBI conformers have no imaginary frequency.

The internal dynamics curves of the pyridinyl moiety around $\mathrm{C}(7)-\mathrm{C}(8)$ bond in $\mathrm{PBI}$ molecule obtained within B3LYP/6-31G and MP2/6-31G methods are presented in Fig. 2. There are three minima on these curves. Configurations of PBI
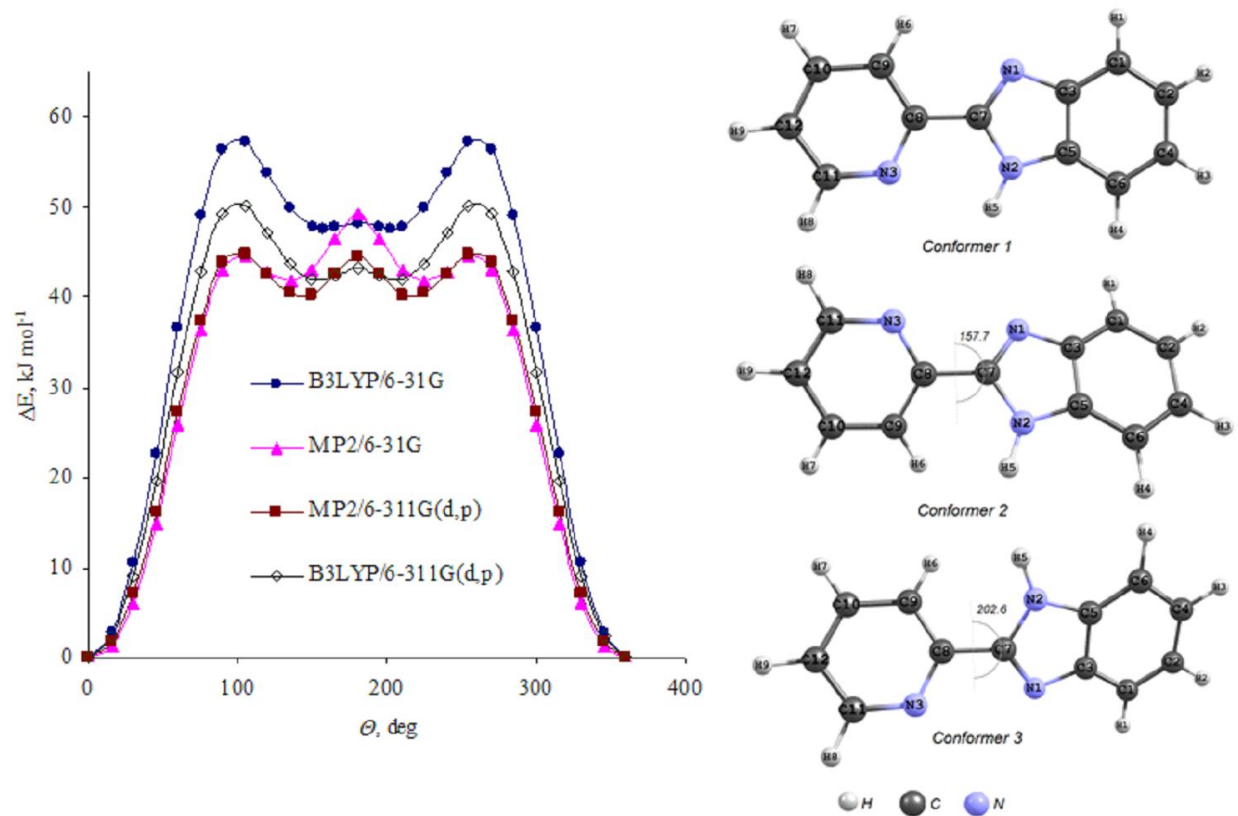

Fig. 2. Conformational energy vs. dihedral angle plots for internal rotation about the $\mathrm{C}(7)-\mathrm{C}(8)$ bond in PBI molecule and the equilibrium configurations of the PBI conformers (B3LYP/6-31G method).

The conformational energies were calculated as the total electronic energy differences between a conformer with the current value of $\Theta$ and the most stable conformer 


\section{ТЕХНИКО-ТЕХНОЛОГИЧЕСКИЕ ИННОВАЦИИ}

molecule with $\Theta$ value of $0^{\circ}$ and $360^{\circ}$ are identical. Minima on the curve corresponded to $\Theta$ value of $157.7^{\circ}$ and $202.6^{\circ}$ (B3LYP method) as well as $135.8^{\circ}$ and $\Theta=224.1^{\circ}$ (MP2 method) are of the same energy, and are characterized by the same value of dipole moment (Table 1). The equilibrium structures of the PBI conformers are shown in Fig. 2. Relative electronic energies of them are listed in Table 1 and indicate that conformer 1 dominate at room temperature wheares the content of conformers 2 and 3 is low. Fig. 3 presents the visualization of HOMO and LUMO for BIP conformers (Table 2).

Experimentally obtained activation free energy for the interconversion between the PBI unequally populated rotamers as reported in [18] are $63.3 \mathrm{~kJ} /$ mol (NMR ${ }^{1} \mathrm{H}$ data) and $59.4 \mathrm{~kJ} / \mathrm{mol}\left(\mathrm{NMR}{ }^{13} \mathrm{C}\right.$ data). Thus rotation barriers obtained within B3LYP method are in reasonable agreement with experimental data.

PBI conformers parameters

\begin{tabular}{|c|c|c|c|c|c|c|}
\hline \multirow{2}{*}{ Parameter } & \multicolumn{3}{|c|}{ B3LYP/6-31G } & \multicolumn{3}{|c|}{ MP2/6-31G } \\
\hline & 1 & 2 & 3 & 1 & 2 & 3 \\
\hline$\Delta E, \mathrm{~kJ} \cdot \mathrm{mol}^{-1}$ & 0 & 47.55 & 47.55 & 0 & 41.78 & 41.78 \\
\hline$\Theta, \operatorname{deg}$ & 0.0 & 157.7 & 202.6 & 0.0 & 135.8 & 224.1 \\
\hline$\mu, \mathrm{D}$ & 2.451 & 5.147 & 5.147 & 2.929 & 5.533 & 5.533 \\
\hline $\mathrm{C}(7)-\mathrm{C}(8), \AA$ & 1.455 & 1.465 & 1.465 & 1.464 & 1.473 & 1.473 \\
\hline $\mathrm{C}(7)-\mathrm{N}(1), \AA$ & 1.332 & 1.328 & 1.328 & 1.354 & 1.349 & 1.349 \\
\hline $\mathrm{C}(7)-\mathrm{N}(2), \AA$ & 1.385 & 1.402 & 1.402 & 1.395 & 1.409 & 1.409 \\
\hline $\mathrm{C}(8)-\mathrm{N}(3), \AA$ & 1.359 & 1.356 & 1.356 & 1.376 & 1.376 & 1.376 \\
\hline $\mathrm{C}(11)-\mathrm{N}(3), \AA$ & 1.348 & 1.346 & 1.346 & 1.369 & 1.369 & 1.369 \\
\hline $\mathrm{C}(8)-\mathrm{C}(9), \AA$ & 1.403 & 1.408 & 1.408 & 1.414 & 1.416 & 1.416 \\
\hline $\mathrm{C}(9)-\mathrm{C}(10), \AA$ & 1.395 & 1.397 & 1.397 & 1.407 & 1.409 & 1.410 \\
\hline $\mathrm{C}(9)-\mathrm{H}(6), \AA$ & 1.083 & 1.085 & 1.085 & 1.089 & 1.092 & 1.092 \\
\hline $\mathrm{C}(3)-\mathrm{N}(1), \AA$ & 1.399 & 1.399 & 1.399 & 1.417 & 1.419 & 1.420 \\
\hline $\mathrm{C}(5)-\mathrm{N}(2), \AA$ & 1.387 & 1.390 & 1.390 & 1.397 & 1.401 & 1.401 \\
\hline $\mathrm{C}(3)-\mathrm{C}(5), \AA$ & 1.426 & 1.422 & 1.422 & 1.435 & 1.431 & 1.431 \\
\hline $\mathrm{C}(1)-\mathrm{C}(3), \AA$ & 1.401 & 1.401 & 1.401 & 1.415 & 1.414 & 1.415 \\
\hline $\mathrm{C}(5)-\mathrm{C}(6), \AA$ & 1.399 & 1.399 & 1.399 & 1.415 & 1.414 & 1.414 \\
\hline $\mathrm{N}(2)-\mathrm{H}(5), \AA$ & 1.008 & 1.006 & 1.006 & 1.013 & 1.012 & 1.012 \\
\hline $\mathrm{C}(1)-\mathrm{H}(1), \AA$ & 1.084 & 1.084 & 1.083 & 1.090 & 1.090 & 1.090 \\
\hline $\mathrm{C}(2)-\mathrm{C}(4), \AA$ & 1.415 & 1.415 & 1.414 & 1.431 & 1.430 & 1.430 \\
\hline $\mathrm{N}(1)-\mathrm{C}(7)-\mathrm{C}(8)$ & 126.5 & 126.3 & 126.3 & 126.1 & 126.3 & 126.3 \\
\hline $\mathrm{C}(7)-\mathrm{C}(8)-\mathrm{C}(9)$ & 121.5 & 121.4 & 121.4 & 121.5 & 120.7 & 120.7 \\
\hline $\mathrm{C}(7)-\mathrm{C}(8)-\mathrm{N}(3)$ & 115.9 & 116.9 & 117.0 & 115.4 & 116.7 & 116.7 \\
\hline $\mathrm{C}(8)-\mathrm{N}(3)-\mathrm{C}(11)$ & 118.2 & 118.5 & 118.4 & 117.4 & 117.3 & 117.3 \\
\hline $\mathrm{N}(1)-\mathrm{C}(7)-\mathrm{N}(2)$ & 112.6 & 111.8 & 111.8 & 112.7 & 112.2 & 112.2 \\
\hline $\mathrm{C}(7)-\mathrm{N}(2)-\mathrm{C}(5)$ & 107.4 & 107.4 & 107.4 & 107.5 & 107.5 & 107.5 \\
\hline $\mathrm{C}(3)-\mathrm{N}(1)-\mathrm{C}(7)$ & 105.1 & 105.7 & 105.7 & 104.3 & 104.7 & 104.7 \\
\hline $\mathrm{N}(1)-\mathrm{C}(3)-\mathrm{C}(5)$ & 109.9 & 110.2 & 110.2 & 110.3 & 110.6 & 110.6 \\
\hline$C(3)-C(5)-C(6)$ & 121.9 & 122.1 & 122.1 & 122.0 & 122.2 & 122.2 \\
\hline
\end{tabular}

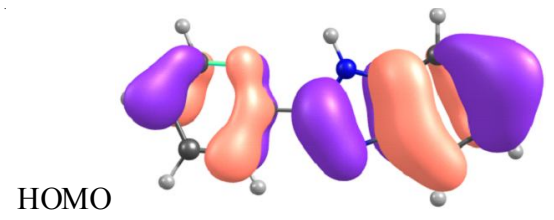

Conformer $1(\Delta \mathrm{E}=4.351 \mathrm{eV})$

LUMO

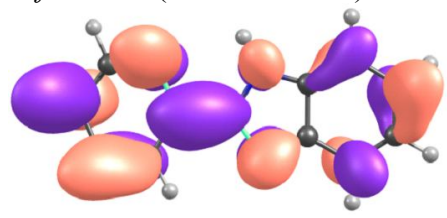

Table 1

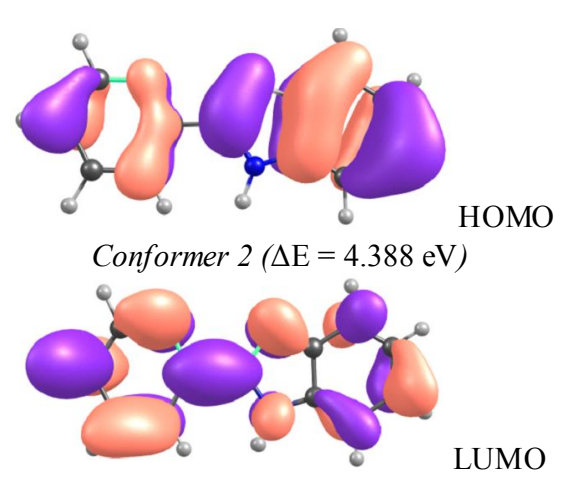

Fig. 3. HOMO and LUMO of the PBI conformers (B3LYP/6-311G(d,p) method) 
PBI rotational barriers values

\begin{tabular}{|c|c|c|c|c|}
\hline \multirow{2}{*}{ Parameter } & \multicolumn{2}{|c|}{ B3LYP } & \multicolumn{2}{c|}{ MP2 } \\
\cline { 2 - 5 } & $6-31 \mathrm{G}$ & $6-311 \mathrm{G}(\mathrm{d}, \mathrm{p})$ & $6-31 \mathrm{G}$ & $6-311 \mathrm{G}(\mathrm{d}, \mathrm{p})$ \\
\hline$\Delta \mathrm{E}_{1>2}, \mathrm{~kJ} \cdot \mathrm{mol}^{-1}$ & 57.24 & 50.14 & 44.50 & 44.86 \\
\hline$\Delta \mathrm{E}_{2>3}, \mathrm{~kJ} \cdot \mathrm{mol}^{-1}$ & 0.67 & 1.30 & 7.44 & 4.24 \\
\hline$\Delta \mathrm{E}_{3>1}, \mathrm{~kJ} \cdot \mathrm{mol}^{-1}$ & 9.69 & 8.24 & 2.72 & 4.51 \\
\hline
\end{tabular}

\section{NMR ${ }^{1} \mathrm{H}$ and ${ }^{13} \mathrm{C}$ chemical shifts}

For the identified conformers of PBI molecule ${ }^{1} \mathrm{H}$ and ${ }^{13} \mathrm{C}$ chemical shifts were estimated. Only two conformers ( 1 and 2$)$ were considered. The MP2/6-31G(d,p) and MP2/6-31G(d,p)/PCM as well as B3LYP/6-31G(d,p) and B3LYP/6-31G(d,p)/ PCM optimized geometries were used for magnetic shielding tensors calculation by standard GIAO method. The chemical shifts of PBI at different computational levels are listed in Table 3 along with the corresponding experimental solution data.

Concerning the spectral patterns of protons and carbons, inspection of Table 3 reveals the following features. The patterns of ${ }^{1} \mathrm{H}$ and ${ }^{13} \mathrm{C}$ spectra of BIP are correctly reproduced at all used computational levels. Although both levels yield qualitatively similar results, the experimental patterns are better reproduced by B3LYP calculations.

When passing to the calculations in the PCM mode solvation accounting leads to more correct results for the MP2 and B3LYP methods. The lowest $\sigma$ values are obtained with B3LYP/6-31G(d,p) basis set. Linear relationships between the experimental chemical shifts and the calculated ones have been obtained for both methods. The correlation coefficients $(R)$ corresponding to obtained dependences are shown in Table 3. Joint account of $s$ and $R$ values indicates possibility of B3LYP method with 6-31G $(\mathrm{d}, \mathrm{p})$ basis set using for the calculation of the BIP chemical shifts. Using of the PCM mode in calculations is preferable as compared to the isolated particle approximation.

Table 3

Experimental and calculated NMR ${ }^{1} \mathrm{H}$ and ${ }^{13} \mathrm{C}$ chemical shifts of PBI

\begin{tabular}{|c|c|c|c|c|c|c|c|}
\hline \multirow{2}{*}{ Atom } & \multicolumn{3}{|c|}{ Conformer 1 } & \multicolumn{3}{c|}{ Conformer 2 } & \multirow{2}{*}{ Experiment } \\
\cline { 2 - 7 } C1 & 132.15 & 127.25 & 126.08 & 133.14 & 128.63 & 126.49 & 118.93 \\
\hline C2 & 132.41 & 127.75 & 129.14 & 132.60 & 127.90 & 129.23 & 122.42 \\
\hline C3 & 157.25 & 152.08 & 151.42 & 157.48 & 151.57 & 150.9 & 143.79 \\
\hline C4 & 133.19 & 129.67 & 130.91 & 133.03 & 129.99 & 131.12 & 122.42 \\
\hline C5 & 144.55 & 139.96 & 141.53 & 144.86 & 139.81 & 141.75 & 134.8 \\
\hline C6 & 120.33 & 114.25 & 117.40 & 119.57 & 112.64 & 117.22 & 111.83 \\
\hline C7 & 158.48 & 154.9 & 157.16 & 156.82 & 153.4 & 156.63 & 148.62 \\
\hline C8 & 155.98 & 155.79 & 155.05 & 160.10 & 155.23 & 154.71 & 150.27 \\
\hline C9 & 133.46 & 127.1 & 128.07 & 133.41 & 122.52 & 127.25 & 123.78 \\
\hline C10 & 143.94 & 141.83 & 144.96 & 142.89 & 140.7 & 144.87 & 136.6 \\
\hline C11 & 156.77 & 154.9 & 157.16 & 159.21 & 157.5 & 158.24 & 148.79 \\
\hline C12 & 135.24 & 128.39 & 131.77 & 134.93 & 127.3 & 131.27 & 121.22 \\
\hline$\sigma$ & 10.31 & 6.11 & 7.46 & 10.64 & 6.10 & 7.42 & - \\
\hline$R$ & 0.98 & 0.99 & 0.99 & 0.98 & 0.98 & 0.99 & - \\
\hline H1 & 8.3114 & 8.04 & 8.244 & 8.4027 & 8.14 & 8.262 & 7.63 \\
\hline H2 & 7.628 & 7.441 & 7.777 & 7.6677 & 7.464 & 7.783 & 7.14 \\
\hline H3 & 7.6081 & 7.439 & 7.800 & 7.627 & 7.457 & 7.817 & 7.14 \\
\hline H4 & 7.8177 & 7.526 & 8.063 & 7.7757 & 7.487 & 8.077 & 7.51 \\
\hline H5 & 10.223 & 9.690 & 10.846 & 8.4752 & 8.536 & 10.415 & 12.88 \\
\hline H6 & 9.0363 & 8.732 & 8.852 & 7.7789 & 7.536 & 8.37 & 8.47 \\
\hline H7 & 8.0075 & 7.875 & 8.392 & 7.9712 & 7.778 & 8.389 & 7.90 \\
\hline H8 & 8.802 & 8.791 & 9.132 & 9.1272 & 9.139 & 9.258 & 8.67 \\
\hline H9 & 7.5145 & 7.255 & 7.819 & 7.5901 & 7.204 & 7.798 & 7.41 \\
\hline$\sigma$ & 0.425 & 0.248 & 0.541 & 0.478 & 0.434 & 0.540 & - \\
\hline$R *$ & 0.92 & 0.94 & 0.99 & 0.68 & 0.68 & 0.90 & - \\
\hline
\end{tabular}

Note. ${ }^{*}$ chemical shift of $\mathrm{H} 5$ was not accounted. 


\section{Conclusions}

A comprehensive study of the 2-(pyridin-2-yl)1H-benzimidazole by experimental $\mathrm{NMR}{ }^{1} \mathrm{H}$ and ${ }^{13} \mathrm{C}$ spectroscopy and molecular modeling methods was performed. Structural parameters of the BIP conformers were obtained by MP2 and B3LYP methods. Rotation barriers obtained within B3LYP method are in reasonable agreement with experimental data. GIAO-calculated NMR chemical shifts $\left({ }^{1} \mathrm{H}\right.$ and $\left.{ }^{13} \mathrm{C}\right)$ as obtained at various computational levels are reported for the 2-(pyridin2-yl)-1H-benzimidazole conformers. For NMR ${ }^{1} \mathrm{H}$ and ${ }^{13} \mathrm{C}$ spectra of the BIP in DMSO-d ${ }_{6}$ MP2 and B3LYP methods approximations with 6-31G $(\mathrm{d}, \mathrm{p})$ basis set allow to obtain the correct spectral pattern. A linear correlations between the calculated and experimental values of the ${ }^{1} \mathrm{H}$ and ${ }^{13} \mathrm{C}$ chemical shifts for the studied molecule were obtained. B3LYP method combined with 6-31G(d,p) basis set and PCM approximation allows to get a better agreement between the calculated and experimental data.

\section{REFERENCES}

1. Chen W., Xi C., Wu Y. Highly Active PD (II) Catalysts With Pyridyl Benzoimidazole Ligands for the Heck Reaction. Journal of Organometallic Chemistry, 2007, vol. 692, pp. 4381-4388.

2. Cossi M., Scalmani G., Rega N., Barone V. New Developments in the Polarizable Continuum Model for Quantum Mechanical and Classical Calculations on Molecules in Solution. J. Chem. Phys., 2002, vol. 117, pp. 43-54.

3. Das S., Guha S., Banerjee A. 2-(2'-Pyridyl) Benzimidazole Based Co (II) Complex as an Efficient Fluorescent Probe for Trace Level Determination of Aspartic and Glutamic Acid in Aqueous Solution: A Displacement Approach. Org. Biomol. Chem., 2011, vol. 9, pp. 7097-7104.

4. Frisch M. J., et al. Gaussian 09, Revision B.01. Gaussian, Inc., Wallingford CT, 2010.

5. Guin M., Maity S., Patwari G.N. InfraredOptical Double Resonance Spectroscopic Measurements on 2-(2'-Pyridyl) Benzimidazole and Its Hydrogen Bonded Complexes With Water and Methanol. Phys. Chem. A, 2010, vol. 114, pp. 83238330.

6. Ishikawa M., Nonoshita K. , Ogino Y., Nagae Y., Tsukahara D., Hosaka H., Maruki H., Ohyama S., Yoshimoto R., Sasaki K., Nagata Y., Eiki J., Nishimura T. Discovery of Novel 2-(Pyridine-2-yl)-1H-
Benzimidazole Derivatives as Potent Glucokinase Activators. Bioorg. Med. Chem. Lett., 2009, vol. 19, pp. 4450-4454.

7. Iyer S.S., Datta A. Microheterogeneity in Native and Cation-Exchanged Nafion Membranes. J. Phys. Chem. B., 2012, vol. 116, pp. 9992-9998.

8. Iyer S.S., Datta A. Influence of External Electrolyte on Ion Exchange in Nafion Membranes. RSC Advances, 2012, vol. 2, pp. 8050-8054.

9. Iyer S.S., Dhrubajyoti S., Dey A., Kundu A., Datta A. 2-(2'-Pyridyl) Benzimidazole as a Fluorescent Probe of Hydration of Nafion Membranes. Indian J. Chem., 1999, vol. 38A, pp. 1223-1227.

10. Maiore L., Aragoni M.C., Deiana C., Cinellu M.A., Isaia F., Lippolis V., Pintus A., Serratrice M., Arca M. Structure-Activity Relationships in Cytotoxic AuI/AuIII Complexes Derived from 2-(2'-Pyridyl) Benzimidazole. Inorg. Chem., 2014, vol. 53 (8), pp. 4068-4080.

11. Mennucci B., Tomasi J. Continuum Solvation Models: A New Approach to the Problem of Solute's Charge Distribution and Cavity Boundaries. J. Chem. Phys., 1997, vol. 106, pp. 5151-5158.

12. Schiffmann R., Neugebauer A., Klein C.D. Metal-Mediated Inhibition of Escherichia Coli Methionine Aminopeptidase: Structure Activity Relationships and Development of a Novel Scoring Function for Metal Ligand Interactions. J. Med. Chem., 2006, vol. 49, pp. 511-522.

13. Sontakke V.A., Ghosh S., Lawande P.P. A Simple Efficient Synthesis of 2-Aryl Benzimidazoles Using Silica-Supported Periodic Acid Catalyst and Evaluation of Anticancer Activity. ISRN Organic Chemistry, 2013, vol. 2, p. 7.

14. Thakur P., Chakravortty V., Dash K.C. Synthesis and Characterization of Lanthanide (III) Complexes of 5-Methyl-2-(2'-Pyridyl) Benzimidazole and 2-(2'-Pyridyl) Benzimidazole. Indian Journal of Chemistry, 1999, vol. 38A, pp. 1223-1227.

15. Tsukamoto G., Yoshino K., Kohono T., Ohtaka H., Kagaya H., Ito K. 2-Substituted Azole Derivatives. 1. Synthesis and Anti-Inflammatory Activity of Some 2-(Substituted-Pyridinyl) Benzimidazoles. J. Med. Chem., 1980, vol. 23, pp. 734-738.

16. Walia R., Hedaitullah M., Naaz S.F., Iqbal Kh., Lamba H.S. Benzimidazole Derivatives - an Overview. Int. J. Research Pharm. Chem., 2011, vol. 3 (1), pp. 565-574.

17. Wolinski K., Hilton J.F., Pulay P. Efficient Implementation of the Gauge-Independent Atomic Orbital Method for NMR Chemical Shift Calculations. J. Am. Chem. Soc., 1990, vol. 112, pp. 8251-8260.

18. Yeh A., Shih Ch., Lin L., Yang Sh., Chang Ch. Variable-Temperature NMR Studies of 2-(Pyridin-2-yl)1H-Benzodimidazole. Life Science Journal, 2009, vol. 6 (4), pp. 1-4. 


\section{МОЛЕКУЛЯРНОЕ МОДЕЛИРОВАНИЕ \\ ВНУТРИМОЛЕКУЛЯРНОЙ ДИНАМИКИ \\ 2-(ПИРИДИН-2-ИЛ)-1Н-БЕНЗИМИДАЗОЛА}

\section{Елена Владимировна Ракша}

Кандидат химических наук, доцент кафедры физической химии, Донецкий национальный университет

elenaraksha@donnu.edu.ua

ул. Университетская, 24, 83055 г. Донецк, Украина

\section{Александр Борисович Ересько}

Инженер,

Институт физико-органической химии и углехимии им. Л.М. Литвиненко, НАН Украины a_eresko2002@yahoo.com

ул. Р. Люксембург, 70, 83114 г. Донецк, Украина

\section{Юлия Васильевна Берестнева}

Аспирант кафедры физической химии,

Донецкий национальный университет

berestnevayuv@mail.ru

ул. Университетская, 24, 83055 г. Донецк, Украина

\section{Алексей Викторович Муратов}

Инженер-химик,

Институт физико-органической химии и углехимии им. Л.М. Литвиненко, НАН Украины a_eresko2002@yahoo.com

ул. Р. Люксембург, 70, 83114 г. Донецк, Украина

\section{Геннадий Ефремович Заиков}

Доктор химических наук, профессор,

заведующий отделом биологической и химической физики полимеров,

Институт биохимической физики им. Н.М. Эмануэля РАН

chembio@sky.chph.ras.ru

ул. Косыгина, 4,119334 г. Москва, Российская Федерация

Аннотация. В работе представлены результаты теоретического исследования внутримолекулярной динамики DFT и MP2 2-(пиридин-2-ил)-1Н-бензимидазола. Этими методами были получены структурные параметры 2-(пиридин-2-ил)-1Н-бензимидазола конформеров; также были оценены барьеры внутреннего вращения. Сравнительный анализ экспериментальных и компьютерных данных NMR-спектроскопии показал, что такой подход может использоваться для оценки $\mathrm{NMR}{ }^{1} \mathrm{H}$ и ${ }^{13} \mathrm{C}$ спектров параметров 2-(пиридин-2-ил)-1Н-бензимидазола.

Ключевые слова: внутримолекулярная динамика, 2-(пиридин-2-ил)-1Н-бензимидазол, химический сдвиг, магнитная постоянная, GIAO, молекулярное моделирование. 